911.3

ст.

- обзяк

ьвівський н ціон льний університетімені в н вул. . орошенк , 41, м. ввів, 79000, кр їн

ро н лізов но зміну кількості н селення міст кр їни з д ними сеукр їнського перепису н селення 2001 р. т д ними ерж вного комітету ст тистики кр їни 32010 р. иявлено регіон льні відмінності пок зник дин міки н селення міст кр їни. иділено групи міст 3 к тегоріями т зміною кількості мешк нців у них. роблено розподіл обл стей кр їни з щорічним пок зником дин міки.

лючові слов : змін кількості н селення, пок зник дин міки, міст .

p нсформ ційні процеси в демогр фічній структурі міського розселення є в жливим чинником у житті суспільств н поч тку ст., оскільки міські поселення посід ють в гоме місце в соці льній т економіко-господ рській сфер х будь-якої кр їни.

и дослідили зміни в кількості н селення міст кр їни, що ст лися в 2001-2010 pp.

2001 р. в кр їні н лічув лося 454 міст , де прожив ло 28 518,4 тис. осіб. 2010 р. кількість міст збільшил сь до 459, мешк нців у них зменшилось н 3 \% і ст новило 27 659,3 тис. осіб. віть при тому, що до к тегорії міст з цей ч с приєдн лося шість селищ міського типу (з н селенням пон д 64 тис.), місто нгулець приєдн но до ривого огу, з г льн кількість жителів зменшил сь н 859,1 тис. (т бл. 1) [2].

блиця 1

ин мік кількості міст кр їни з к тегоріями в 2001-2010 pp. [3]

\begin{tabular}{|c|c|c|}
\hline \multirow{2}{*}{ тегорії з кількістю н селення } & \multicolumn{2}{|c|}{ оки } \\
\cline { 2 - 3 } & $\mathbf{2 0 0 1}$ & $\mathbf{2 0 1 0}$ \\
\hline он д 1 млн (міст -мільйонери) & 5 & 4 \\
\hline 500 тис. -1 млн (дуже великі) & 4 & 5 \\
\hline 100 тис. -500 тис. (великі) & 36 & 36 \\
\hline 50 тис. -100 тис. (середні) & 56 & 46 \\
\hline 10 тис. -50 тис. (м лі) & 271 & 275 \\
\hline о 10 тис. (дуже м лі) & 82 & 93 \\
\hline зом & $\mathbf{4 5 4}$ & $\mathbf{4 5 9}$ \\
\hline
\end{tabular}

період 2001-2010 pр. в кр їні н одне місто-мільйонер ст ло менше. ізко зменшил ся кількість середніх міст (з 56 до 46). томість кількість м лих і дуже м лих міст збільшил ся, що свідчить про зн чне зменшення кількості жителів у міст х. кщо у 2001 р. в середньому в одному місті прожив ло 62,8 тис. осіб, то у 2010 р. - 60,3 тис.

(C) обзяк ., 2012 
уже добре вир ж є зміни в кількості н селення пок зник дин міки. ля цього ми використ ли т ку формулу:

$$
\mathrm{D}=\left(\mathrm{Q}_{2001} / \mathrm{Q}_{2010}\right) * 100 \%-100 \% ;
$$

де D - пок зник дин міки; Q - кількість н селення у відповідному році.

розрізі н йбільших дміністр тивних одиниць дин мік н селення міст з період 2001-2010 років н веден в т бл. 2 .

ві третини регіонів м ють нег тивну дин міку н селення міст. семи обл стей цей пок зник ст новить $-5 \%$ і менше. екордсменом тут $є$ уг нськ обл., де н селення міст зменшилось н $9 \%$, тобто кожного року регіон ст більно втр ч в $1 \%$ н селення. изькі пок зники у онецькій (-8\%), умській (-8\%), іровогр дській (-7 \%) обл стях. ише три обл сті м ють позитивну дин міку н селення міст з період $2001-$ 2010 pp. ( ернівецьк , в но- р нківськ, інницьк ). роте, вон незн чн, тільки в меж x 1-2\%. фоні нег тивної тенденції зменшення н селення міст виділяеться столиця кр їни, де пок зник ст новить $+7 \%$.

блиця 2

ількість н селення міст кр їни т пок зник дин міки у 2001-2010 pp. [2]

\begin{tabular}{|c|c|c|c|}
\hline $\begin{array}{l}\text { дміністр тивно-територі льн } \\
\text { одиниця }\end{array}$ & $\begin{array}{r}\text { ис. осіб } \\
\text { у } 2001 \mathrm{p} .\end{array}$ & $\begin{array}{l}\text { ис. осіб } \\
\text { у } 2010 \text { p. }\end{array}$ & $\mathrm{D}, \%$ \\
\hline М. иїв & 2611,3 & 2785,1 & +7 \\
\hline ернівецьк & 325,1 & 331,8 & +2 \\
\hline інницьк & 671,2 & 675,5 & +1 \\
\hline в но- $\mathrm{p}$ нківськ & 486,2 & 489,9 & +1 \\
\hline олинськ & 432,0 & 433,7 & 0 \\
\hline иївськ & 851,5 & 854,3 & 0 \\
\hline івненськ & 467,0 & 468,7 & 0 \\
\hline мельницьк & 633,5 & 636,2 & 0 \\
\hline м. ев стополь & 353,0 & 351,9 & 0 \\
\hline к рп тськ & 348,9 & 344,4 & -1 \\
\hline ьвівськ & 1445,2 & 1436,3 & -1 \\
\hline деськ & 1470,8 & 1441,3 & -2 \\
\hline ернопільськ & 414,9 & 403,4 & -3 \\
\hline рківськ & 1905,2 & 1850,3 & -3 \\
\hline втономн еспублік рим & 1013,6 & 972,0 & -4 \\
\hline итомирськ & 614,6 & 588,8 & -4 \\
\hline порізьк & 1336,9 & 1277,7 & -4 \\
\hline икол ївськ & 740,9 & 715,3 & -4 \\
\hline оЛТ всьК & 840,0 & 803,1 & -4 \\
\hline ерк ськ & 684,1 & 659,1 & -4 \\
\hline ніпропетровськ & 2725,5 & 2587,8 & -5 \\
\hline ернігівськ & 607,9 & 579,8 & -5 \\
\hline ерсонськ & 527,2 & 494,9 & -6 \\
\hline умськ & 756,0 & 706,8 & -7 \\
\hline онецьк & 3915,8 & 3627,7 & -8 \\
\hline іровогр дськ & 538,3 & 494,8 & -8 \\
\hline уг нсьК & 1800,7 & 1647,2 & -9 \\
\hline кр їн & 28518,4 & 27659,3 & -3 \\
\hline
\end{tabular}


йліпш ситу ція н 3 ході кр їни, де н селення у міст х зрост $є$ бо пр ктично не змінюється (від +2 до -1 \%). ише у ернопільській обл. пок зник дин міки ст новить $-3 \%$. північних обл стях спостеріг ють досить високе зменшення н селення міст - від -4 до -7 \%. ут виділяється иївськ обл. (0 \%), оскільки н міст , що входять до їі скл ду ( ров ри, ориспіль, ишневе, ишгород), зн чно вплив є столиця кр їни. хідні обл сті м ють н йнижчі пок зники в кр їні - від -3 до -9\%.

івденний регіон т кож м є від'ємну дин міку кількості н селення міст - від $-2 \%$ ( деськ обл.) до -6 \% ( ерсонськ обл.). центр льних обл стях пок зник зміни теж нег тивний - від -4 до $-8 \%$. ільки у інницькій обл. він ст новить $+1 \%$.

г лом н тлі нег тивної тенденції щодо зменшення н селення міст кр їни виділяється $з$ хідний регіон з включенням иївської т інницької обл стей, де кількість мешк нців пр ктично не змінюється бо н віть дещо зрост $є$ (див. рисунок).

т бл. 3 б чимо, що в середньому одне місто кр їни втр тило $5 \%$ н селення. кщо взяти 3 к тегоріями, то простежується чітк послідовність: чим більше місто, тим менше воно втр тило мешк нців у відсотковому еквів ленті. н вп ки, чим місто менше, тим воно відчутніше втр ч є жителів. прикл д, серед міст-мільйонерів пок зник дин міки ст новить $0 \%$. к тегоріях великих міст цей пок зник зміни - $-3 \%$. середніх і м лих міст х н селення зменшується н $5 \%$. йгірш ситу ція в дуже м лих міст х, де кількість жителів зменшується в середньому н $8 \%$.

блиця 3

оК зник дин міки н селення в середньомун одне місто кр їни 3 к тегоріями в 2001-2010 pp.

\begin{tabular}{|c|c|}
\hline тегорії 3 кількістю н селення & D, $\%$ \\
\hline он д 1 млн & 0 \\
\hline 500 тис. -1 млн & -3 \\
\hline 100 тис. -500 тис. & -3 \\
\hline 50 тис. -100 тис. & -5 \\
\hline 10 тис. -50 тис. & -5 \\
\hline о 10 тис. & -8 \\
\hline середньому по кр $\boldsymbol{i} \boldsymbol{i}$ & $\mathbf{- 5}$ \\
\hline
\end{tabular}

еред 459 міст кр їни лише 50 м ють позитивний пок зник зрост ння н селення (т бл. 4). е ст новить $11 \%$ від з г льної кількості міст.

бсолютно м ксим льний приріст н селення з фіксов ний у місті убляни ьвівської обл., де кількість жителів збільшил сь н $29 \%$ бо з 8,5 до 11 тис. исокими пок зник ми дин міки кількості н селення (пон д 8 \%) вирізняються т кож міст жне, еплод р, ллічівськ ( деської обл.); овий линів і инники ( ьвівської обл.); ров ри і ишгород ( иївської обл.); нкерм н ( ев стопольської міської р ди). ут кількість жителів збільшув лось від 1 до $2 \%$ щороку. тже, простежується тенденція до збільшення н селення м лих міст, що розміщені н вколо дуже великих міст і містмільйонерів. кож зрост є кількість мешк нців у деяких припортових м лих і середніх міст $\mathrm{x}$.

он д $80 \%$ міст кр їни м ють нег тивний пок зник дин міки н селення. е в $10 \%$ кількість мешк нців пр ктично не змінюється. 


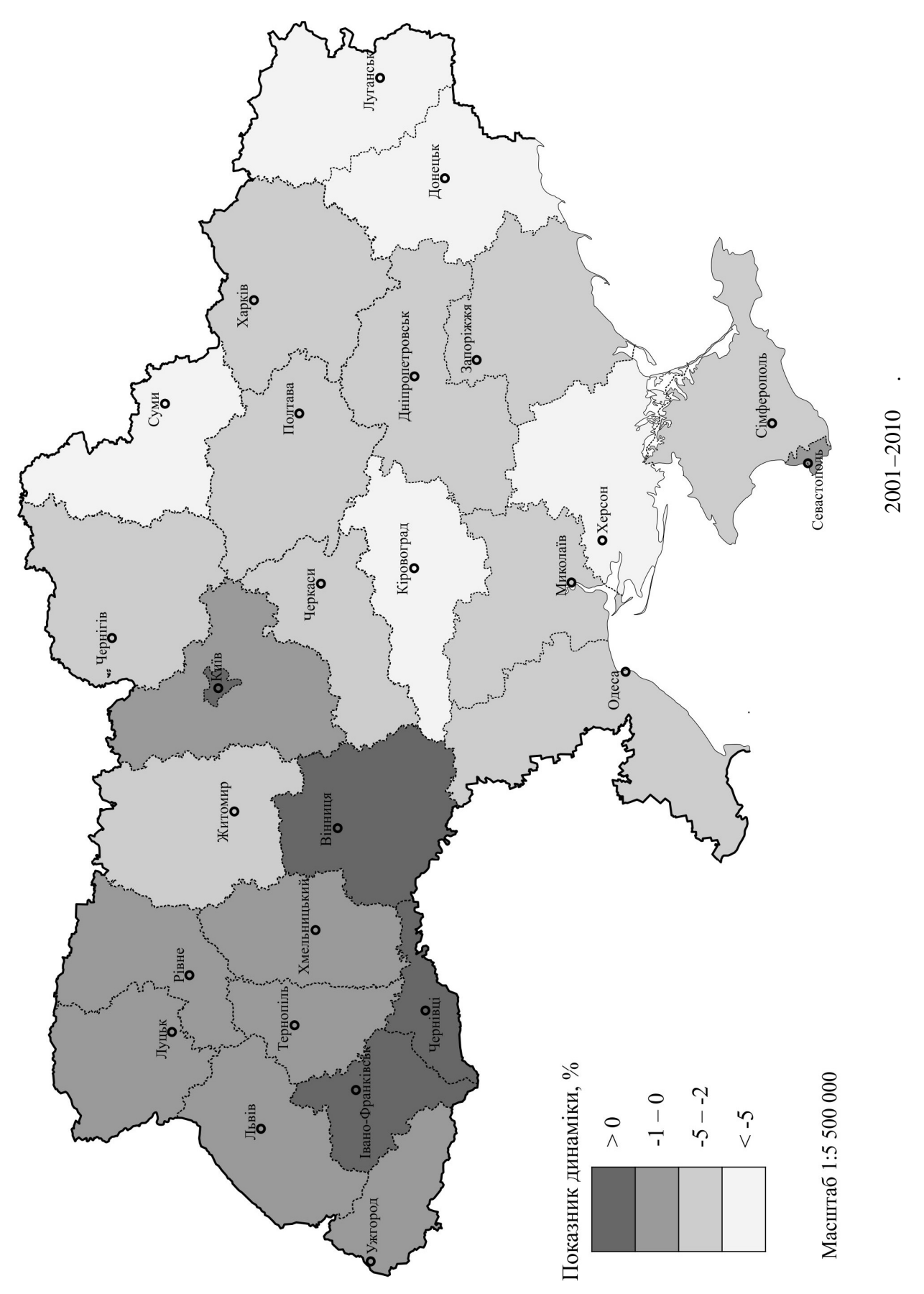


озподіл міст кр їни з пок зником дин міки н селення по к тегоріях 3 2001-2010 pp.

\begin{tabular}{|c|c|c|c|c|c|c|c|c|c|c|}
\hline \multirow{2}{*}{\multicolumn{2}{|c|}{$\begin{array}{r}\text { тегорії } 3 \\
\text { кількістю } \\
\text { н селення }\end{array}$}} & \multicolumn{8}{|c|}{ ількість міст 3 пок ЗНиком } & \multirow{3}{*}{\begin{tabular}{|r|}
- \\
$30 M$ \\
4
\end{tabular}} \\
\hline & & \multirow[t]{2}{*}{$\begin{array}{l}\text { пон д } \\
+10 \% \\
\end{array}$} & \multirow{2}{*}{$\begin{array}{c}+6 \%- \\
+10 \% \\
1\end{array}$} & \multirow[t]{2}{*}{$\begin{array}{l}+2 \%- \\
+5 \% \\
\end{array}$} & \multirow{2}{*}{$\begin{array}{l}+1 \%- \\
-1 \% \\
1\end{array}$} & \multirow{2}{*}{$\begin{array}{l}-2 \%- \\
-5 \% \\
2\end{array}$} & \multirow[t]{2}{*}{$\begin{array}{l}-6 \%- \\
-10 \%\end{array}$} & \multirow[t]{2}{*}{$\begin{array}{l}-11 \%- \\
-15 \%\end{array}$} & \multirow[t]{2}{*}{$\begin{array}{l}\text { менше } \\
-15 \%\end{array}$} & \\
\hline ОН д & $\mathrm{K}-\mathrm{Tb}$ & & & & & & & & & \\
\hline 1 млн & $\%$ & & 25 & & 25 & 50 & & & & 100 \\
\hline \multirow{2}{*}{$\begin{array}{c}500 \text { тис. - } \\
1 \text { млн } \\
\end{array}$} & K-Tb & & & & 1 & 4 & & & & 5 \\
\hline & $\%$ & & & & 20 & 80 & & & & 100 \\
\hline \multirow{2}{*}{$\begin{array}{l}100 \text { тис. }- \\
500 \text { тис. }\end{array}$} & K-Tb & & & 6 & 5 & 12 & 13 & & & 36 \\
\hline & $\%$ & & & 17 & 14 & 33 & 36 & & & 100 \\
\hline \multirow{2}{*}{$\begin{array}{l}50 \text { тис. - } \\
100 \text { тис. }\end{array}$} & $\mathrm{K}-\mathrm{Tb}$ & & 3 & 2 & 7 & 13 & 11 & 7 & 3 & 46 \\
\hline & $\%$ & & 7 & 4 & 15 & 28 & 24 & 15 & 7 & 100 \\
\hline \multirow{2}{*}{$\begin{array}{l}10 \text { тис. - } \\
50 \text { тис. }\end{array}$} & $\mathrm{K}-\mathrm{Tb}$ & 6 & 6 & 16 & 39 & 77 & 79 & 43 & 9 & 275 \\
\hline & $\%$ & 2 & 2 & 6 & 14 & 28 & 29 & 16 & 3 & 100 \\
\hline \multirow{2}{*}{$\begin{array}{l}\text { о } 10 \\
\text { тис. }\end{array}$} & K-Tb & 1 & 2 & 7 & 9 & 26 & 32 & 11 & 5 & 93 \\
\hline & $\%$ & 1 & 2 & 8 & 10 & 28 & 34 & 12 & 5 & 100 \\
\hline \multirow[t]{2}{*}{$\begin{array}{l}\text { зом по } \\
\text { кр їні }\end{array}$} & $\begin{array}{l}\text { K- } \\
\text { Tb }\end{array}$ & 7 & 12 & 31 & 62 & 134 & 135 & 61 & 17 & 459 \\
\hline & $\%$ & 2 & 3 & 7 & 13 & 29 & 29 & 13 & 4 & 100 \\
\hline
\end{tabular}

йменший пок зник дин міки кількості н селення у міст х кр їни з фіксов ний у м. рвінкове рківської обл. - $-20 \%$. ількість жителів тут зменшил сь 313 до 10,4 тис. дев'ять років цей н селений пункт утр тив $1 / 5$ н селення. пон д $15 \%$ зменшил сь кількість жителів у міст х еплогірськ, іровськ, хрушеве ( уг нської обл.); углегірськ, р сний им н, нокомун рівськ, орез, остянтинівк , н кієве, ірник ( онецької обл.); уринь ( умської обл.); игирин ( ерк ської обл.); льянівк ( іровогр дської обл.); ки ( ). і міст втр ч ють щороку 1,5-2,0\% н селення.

т бл. 5 б чимо, що в онецькій, уг нській, порізькій, ернігівській т умській обл стях в усіх без винятку міст х відбув ється щорічне зменшення кількості н селення н $\quad 0,5-2,0 \%$. іст , де щорічний пок зник дин міки нижче $-1 \%$, ст новлять не менше третини від з г льної кількості т ких поселень. в уг нській обл. т ких міст $73 \%$. обто с ме в цих північно-східних і східних регіон х спостеріг ють швидке зменшення кількості мешк нців у міст х. е в низці обл стей - итомирській, ерк ській, іровогр дській, икол ївській, ерсонській, рківській - є невеликий відсоток міст, де кількість н селення пр ктично не змінюється. більшості ж цих поселень кількість мешк нців т кож зменшується.

блиця 5

озподіл міст кр їни з щорічним пок зником дин міки н селення, \%

\begin{tabular}{|l|c|c|c|c|c|}
\hline $\begin{array}{c}\text { дміністр тивно-територі льн } \\
\text { одиниця }\end{array}$ & он д 1 & о 1 & меж х 0 & о -1 & енше -1 \\
\hline 1 & 2 & 3 & 4 & 5 & 6 \\
\hline втономн еспублік рим & - & 6 & 6 & 75 & 13 \\
\hline інницьк & - & 6 & 33 & 61 & - \\
\hline олинськ & - & 27 & 27 & 36 & 10 \\
\hline ніпропетровськ & - & 10 & 25 & 50 & 15 \\
\hline онецьк & - & - & - & 58 & 42 \\
\hline
\end{tabular}




\begin{tabular}{|l|c|c|c|c|c|}
\multicolumn{1}{|c|}{ кінчення т бл. 5 } \\
\hline итомирськ & 2 & 3 & 4 & 5 & 6 \\
\hline к рп тськ & - & - & 18 & 73 & 9 \\
\hline порізьк & - & 9 & 36 & 55 & - \\
\hline в но- р нківськ & - & - & - & 64 & 36 \\
\hline иївськ & - & 20 & 40 & 40 & - \\
\hline іровогр дськ & 8 & 15 & 23 & 31 & 23 \\
\hline уг нськ & - & 8 & - & 33 & 59 \\
\hline ьвівськ & - & - & - & 27 & 73 \\
\hline икол їськ & 7 & 14 & 20 & 57 & 2 \\
\hline деськ & - & 12 & - & 44 & 44 \\
\hline олт вськ & 16 & 5 & 21 & 42 & 16 \\
\hline івненськ & - & 7 & 7 & 66 & 20 \\
\hline умськ & - & 40 & 30 & 30 & 10 \\
\hline ернопільськ & - & - & - & 67 & 33 \\
\hline рківськ & - & 17 & 33 & 44 & 6 \\
\hline ерсонськ & - & - & 6 & 53 & 41 \\
\hline мельницьк & - & 11 & - & 78 & 11 \\
\hline ерк ськ & - & 31 & 8 & 61 & - \\
\hline ернівецьк & - & - & 19 & 50 & 31 \\
\hline ернігівськ & - & 27 & - & 55 & 18 \\
\hline & - & - & - & 63 & 37 \\
\hline
\end{tabular}

г лом н поч тку ст. спостеріг ємо т кі процеси: зменшення середніх і великих міст т різке збільшення м лих; зн чні втр ти кількості н селення міст н сході й півдні кр їни т ст біліз ція цього процесу н 3 ході; простежується чітк 3 кономірність пок зник дин міки н селення щодо поселень різних груп людності - чим більше місто, тим менше воно втр тило мешк нців, і н вп ки, чим місто менше, тим воно відчутніше втр ч є жителів; виявляється територі льн диференці ція щорічного пок зник дин міки н селення міст кр їни - у з хідних, інницькій і иївській обл стях, у більшості міст, він ст новить $0 \%$, н решті території кр їни - від -1,0 до -1,5\%.

1. ерж вн служб ст тистики кр їни. сеукр їнський перепис н селення 2001 року. ежим доступу : http://www.ukrcensus.gov.ua

2. ерж вн служб ст тистики кр їни. ежим доступу : http://www.ukrstat.gov.ua

3. іські поселення світу. вроп . кр їн .

ежим доступу : http://www.citypopulation.de/Ukraine.html

4. т тистичн інформ ція по н селенню хідної вропи. ежим доступу : http://www.pop-stat.mashke.org 


\section{DYNAMICS OF URBAN POPULATION IN UKRAINE AT BEGINNING OF 21 CENTURY}

\section{R. Kobzyak}

Ivan Franko National University of Lviv, . Doroshenko St., 41, UA - 79000 Lviv, Ukraine

The change of number of Ukrainian cities' population was analyzed on the basis of statistical data of Ukrainian census in 2001 and data of State Statistical Committee of Ukraine. There was discovered the difference of movements' index of Ukrainian cities' population. The groups of cities' were marked by the change of their inhabitants' quantity. The distribution of Ukrainian regions was done on the basis of annual index of population's movement.

Key words: change of number, movements' index, cities.

I

- обзяк

ьвовский н иион льный университет имени в н

ул. . орошенко, 41, г. ьвов, 79000, кр ин

о д нным сеукр инской переписи н селения 2001 г. и д нным осуд рственного комитет ст тистики кр ины 32010 г., про н лизиров но изменения численности н селения городов кр ины. ссмотрено регион льные отличия пок $з$ теля дин мики н селения городов кр ины. ыделено группы городов по к тегориям и изменению количеств жителей в них. дел но р спределение обл стей кр ины по ежегодным пок з телем дин мики.

лючевые слов : изменение количеств н селения, пок з тель дин мики, город . 